ISSN : 2303-1514 | E-ISSN : 2598-5949

\title{
PROBLEM BASED LEARNING MODEL ON MATH SUBJECT TO INCREASE STUDENT' LEARNING OUTCOMES AT GRADE V SDN 05 PADANG PASIR
}

\author{
Imam Taufiq ${ }^{1}$, Elvia Sukma ${ }^{2}$, Tri Susilawati ${ }^{3}$ \\ ${ }^{1,2}$ Universitas Negeri Padang, Padang, Indonesia \\ ${ }^{3}$ SDN 05 Padang Pasir, Padang, Indonesia \\ Imammtaufiqq@gmail.com, ${ }^{2}$ elfiasukma105@gmail.com, ${ }^{3}$ trisusilawati1970@gmail.com
}

\section{MODEL PROBLEM BASED LEARNING DALAM PEMBELAJARAN MATEMATIKA UNTUK MENINGKATKAN HASIL BELAJAR PESERTA DIDIK DI KELAS V SDN 05 PADANG PASIR}

\begin{tabular}{|c|c|}
\hline ARTICLE HISTORY & ABSTRACT \\
\hline $\begin{array}{l}\text { Submitted: } \\
18 \text { Juli } 2021 \\
18^{\text {th }} \text { July } 2021\end{array}$ & $\begin{array}{l}\text { Abstract: This research was motivated by the fact that students' mathematics learning outcomes at } \\
\text { grade V of SDN } 05 \text { Padang Pasir, Padang was still low. This was due to the covid-19 pandemic that hit } \\
\text { Indonesia and learning model which was suitable to the students' characteristics had not been applied. } \\
\text { The purpose of this research was to describe the application of Problem Based Learning (PBL) learning } \\
\text { model to improve students' learning outcomes at grade Vof SDN } 05 \text { Padang Pasir, Padang. The type of } \\
\text { this research was Classroom Action Research using qualitative and quantitative approaches. Research } \\
\text { procedures included planning, implementation, observation, and reflection. Research data were } \\
\text { obtained from observations and actions as well as test results. The source of data was the process and } \\
\text { results of the implementation of learning by using PBL model on data processingg material. This } \\
\text { research was conducted in Semester II of the academic year 2020/2021. The research subjects were a } \\
\text { teacher as the observer, the researcher as practice, and grade V students as many as } 25 \text { people. The } \\
\text { results showed an increase in the average of students' learning outcomes in Cycle I } 68.95 \text { to } 87.8 \text { in } \\
\text { Cycle II. The results of the RPP observations increased from } 88.9 \% \text { in cycle I to } 100 \% \text { in cycle II. The } \\
\text { results of observations for the teacher's and students' aspects in cycle I was } 75 \% \text { and increased to } \\
100 \% \text { in cycle II. It was said that PBL model improved the mathematics learning outcomes of data } \\
\text { processing materials at grade V of SDN } 05 \text { Padang Pasir, Padang. }\end{array}$ \\
\hline
\end{tabular}

Keywords: problem based learning, learning outcomes

Accepted:

08 Agustus 2021

08 ${ }^{\text {th }}$ August 2021

Published:

27 Agustus 2021

$27^{\text {th }}$ August 2021

\begin{abstract}
Abstrak: Penelitian ini dilatarbelakangi hasil belajar matematika peserta didik masih rendah. Hal ini disebabkan oleh keadaan pandemi covid yang melanda indonesia dan belum diggunakan model pembelajaran yang sesuai karakteristik peserta didik. Tujuan dari penelitian ini adalahmendeskripsikan penerapan model pembelajaran Problem Based Learning (PBL) untuk meningkatkan hasil belajar di kelas V SDN 05 Padang Pasir Kota Padang. Jenis penelitian ini adalah Penelitian Tindakan Kelas menggunakan pendekatan kualitatif dan kuantitatif. Prosedur penelitian meliputi perencanaan, pelaksanaan, pengamatan, dan refleksi. Data penelitian berupa hasil pengamatan dan tindakan serta hasil tes. Sumber data adalah proses dan hasil pelaksanaan pembelajaran dengan menggunakan model PBL pada materi pengolahan data. Penelitian ini dilaksanakan pada Semester II Tahun Ajaran 2020/2021. Subjek penelitian adalah guru selaku observer, peneliti selaku praktisi, dan peserta didik kelas $V$ sebanyak 25 orang. Hasil penelitian menunjukkan peningkatan rata-rata hasil belajar peserta didik pada siklus I 68,95 menjadi 87,8 pada siklus II. Hasil pengamatan RPP pada siklus I dari 88,9\% menjadi $100 \%$ pada siklus II. Hasil pengamatan aspek guru dan peserta didik pada siklus I adalah 75\% menjadi $100 \%$ pada siklus II. Dapat disimpulkan bahwa, model PBL dapat meningkatkan hasil belajar dalam pembelajaran matematika materi pengolahan data di kelas V SDN 05 Padang Pasir Kota Padang.
\end{abstract}

Keywords: problem based learning, learning outcomes

\section{CITATION}

Taufiq, I., Sukma, E., \& Susilawati, T. (2021). Problem Based Learning Model on Math Subject to Increase Student' Learning Outcomes at Grade V SDN 05 Padang. Primary: Jurnal Pendidikan Guru Sekolah Dasar, 10 (4), 1054-1061. DOI: http://dx.doi.org/10.33578/jpfkip.v10i4.8479. 


\section{PENDAHULUAN}

Pembelajaran matematika memberikan peranan penting dalam kehidupan sehari-hari. Pembelajaran matematika merupakan pembelajaran yang harus dikuasai dengan pemahaman yang baik agar mencapai hasil yang maksimal, serta membutuhkan dukungan semua pihak yang terlibat di dalam dunia pendidikan. Supaya pelaksanaan pembelajaran dapat mencapai tujuan dari pembelajaran matematika tersebut. Kemampuan Peserta didik dalam memahami konsep matematika untuk menyelesaikan soal-soal akan membantu peserta didik mampu mengaplikasikan pembelajaran tersebut di dalam kehidupan sehari-hari yang menjadi tujuan dari pembelajaran matematika. Kemampuan pemahaman ini akan terlihat dari nilai hasil pembelajaran matematika yang diperoleh peserta didik.

Hasil belajar matematika Peserta didik ini tidak lepas dari proses pembelajaran yang berlangsung sehari-hari. Bagaimana cara mengajar, mendidik, dan strategi maupun metode yang digunakan dalam pengelolaan kelas serta media yang digunakan selama proses pembelajaran berlangsung yang menjadi faktor pencapaian hasil belajar. "The low learning outcomes of student can not be separated from the learning process that lasted for this". Yang dimaksud bahwa hasil belajar yang rendah tidak dapat dipisahkan dari proses pembelajaran yang berlangsung (Desyandri dkk, 2018).

Kita mengetahui proses pembelajaran sekarang berlangsung secara campur daring luring yang mana peserta didik dan guru belum terbiasa melaksanakannya. Hal ini banyak berdampak dalam pelaksanaan pembelajaran itu sendiri sehingga membuat hasil belajar peserta didik rendah. Oleh karena itu, guru perlu mengetahui keberhasilan peserta didik dapat ditentukan dari beberapa faktor antara lain faktor internal dan eksternal. Faktor yang timbul dari dalam diri peserta didik, antara lain kemauan, rasa takut, tingkat intelektual dan sebagainya. Sedang faktor eksternal dapat berupa pendekatan pengajaran, metode yang digunakan, alat peraga yang kreatif dan inovatif, dan sumber-sumber lain. Kesemuanya itu akan berpengaruh terhadap keberhasilan pembelajaran.

Peneliti melakukan observasi dalam bentuk pengamatan yang dilakukan di kelas $\mathrm{V}$ SDN 05 Padang Pasir Padang pada tanggal 14 dan 19 Januari 2021. Masalah yang nampak adalah hasil belajar dan pencapaian peserta didik terhadap pembelajaran di kelas V. Hasil belajar beberapa Peserta didik sedikit yang diatas KKM atau masih berada sebatas KKM bahkan ada pula yang berada dibawah KKM yang telah ditetapkan oleh sekolah. KKM yang telah ditetapkan adalah 75. Hasil belajar rendah yang ditemukan adalah penilaian harian. Menurut Kemendikbud (2015) "Penilaian harian $(\mathrm{PH})$ adalah kegiatan yang dilakukan secara periodik untuk mengukur pencapaian kompetensi peserta didik setelah menyelesaikan satu Kompetensi Dasar (KD) atau lebih".

Berikut tabel persentase hasil penilaian harian $(\mathrm{PH})$ matematika semester ganjil peserta didik kelas V SDN 05 Padang Pasir Kota Padang masih belum maksimal atau rendah:

Tabel 1. Ketuntasan Siswa

\begin{tabular}{ccccccc} 
Jumlah & KKM & Rata-rata & \multicolumn{2}{c}{ Tuntas } & \multicolumn{2}{c}{ Tidak Tuntas } \\
\cline { 4 - 6 } $\begin{array}{c}\text { Peserta } \\
\text { Didik }\end{array}$ & & Nilai Hasil & Jumlah & Persentase & Jumlah Peserta & Persentase \\
Belajar & Peserta Didik & & \\
\hline 25 & & 59.84 & 7 & $28 \%$ & 18 & $72 \%$
\end{tabular}




\section{PRIMARY: JURNAL PENDIDIKAN GURU SEKOLAH DASAR \\ VOLUME 10 NOMOR 4 AGUSTUS 2021 \\ ISSN : 2303-1514 | E-ISSN : 2598-5949 \\ DOI : http://dx.doi.org/10.33578/jpfkip.v10i4.8479 \\ https://primary.ejournal.unri.ac.id/index.php/JPFKIP}

Berdasarkan tabel di atas, diketahui bahwa terdapat $28 \%$ atau 7 dari 25 peserta didik yang mendapatkan nilai di atas KKM, sedangkan $72 \%$ atau 18 dari 25 peserta didik mendapat nilai di bawah KKM dengan nilai KKM yang sudah ditentukan adalah 75. Hasil tersebut menunjukkan bahwa hasil belajar peserta didik di kelas tersebut belum memenuhi ketuntasan klasikal. Sebagaimana menurut Trianto (2010) suatu kelas dikatakan tuntas belajarnya (ketuntasan klasikal) jika dalam kelas tersebut terdapat $\geq 85 \%$ peserta didik yang telah tuntas belajarnya. Sesuai dengan pendapat yang dikemukakan Trianto, maka dapat disimpulkan bahwa hasil belajar peserta didik kelas $\mathrm{V}$ belum memenuhi ketuntasan klasikal. Untuk itu, kelas V SDN 05 Padang Pasir Kota Padang memerlukan suatu tindakan untuk meningkatkan hasil belajar matematika peserta didik. Tindakan yang lakukan adalah diperlukannya model pembelajaran yang inovatif. Salah satu model pembelajaran yang dapat digunakan adalah model pembelajaran problem based learning.

Model pembelajaran Problem Based Learning merupakan salah satu model pembelajaran yang bisa diterapkan dalam pembelajaran matematika. Selain itu, model Problem Based Learning juga model pembelajaran yang berpusat pada Peserta didik (students center). Menurut Ngalimun (2017:172) "Model problem based learning (PBL) adalah suatu model pembelajaran yang melibatkan peserta didik untuk memecahkan suatu masalah melalui tahap-tahap metode ilmiah sehingga peserta didik dapat mempelajari pengetahuan yang berhubungan dengan masalah tersebut dan sekaligus memiliki keterampilan untuk memecahkan masalah". Model pembelajaran yang demikian membuat pembelajaran yang melibatkan peserta didik dalam investigasi dan kegiatan tugas-tugas bermakna lain, yang akan menjadikan pembelajaran lebih bermakna dan lama diingat oleh peserta didik. Mereka sendirilah yang menemukan atau mengasimilasikan sendiri konsep, prinsipnya melalui kegiatan-kegiatan yang dalam pembelajaran.
Salah satu materi pembelajaran matematika yang dapat menerapkan model pembelajaran Problem Based Learning pada kelas V semester II berdasarkan kurikulum 2013 adalah materi pengolahan data dengam KD 3.7 Menjelaskan data yang berkaitan dengan diri Peserta didik atau lingkungan sekitar serta cara pengumpulannya dan KD 4.7 Mengidentifikasi data yang berkaitan dengan diri Peserta didik atau lingkungan sekitar serta cara pengumpulannya. Menurut Tarigan (2006: 114) "pengolahan data adalah suatu data yang diperoleh dari hasil pengamatan dengan maksud agar data yang diperoleh dapat cepat dilihat dan dibaca". Pembelajaran pengolahan data diharapkan bukan hanya sekedar guru menjelaskan apa itu pengolahan data dan bagaimana menyajikan suatu data tersebut, namun hendaknya guru meminta peserta didik untuk menemukan sendiri bagaimana mengolah suatu data yang benar dan baik itu. Pembelajaran akan menjadi bermakna dan lama diingat oleh peserta didik mengenai konsep dan prinsip-prinsip dari pengolahan data, sehingga dapat meningkatkan hasil belajar peserta didik.

Keunggulan dari model problem based learning ini yaitu : (1) Penerapan dalam pembelajaran akan dapat mengarahkan peserta didik untuk belajar bermakna, (2) Peserta didik dapat menggabungkan teori-teori yang telah dipelajari dengan keterampilan yang dimiliki secara bersamaan serta peserta didik dapat menerapkannya dalam konteks yang berhubungan dengan pengetahuan dan keterampilan tersebut, (3) Peserta didik dapat menumbuh kembangkan keterampilan berpikir kritisnya, sifat inisiatif, motivasi dari dalam diri serta peserta didik dapat motivasi internal untuk belajar, dan dapat mengembangkan hubungan interpersonal yang ada di dalam dirinya sendiri ketika ia bekerja dalam kelompoknya (Widiasworo, 2017:173-174).

Keberhasilan dari penerapan penggunaan model problem based learning dalam pembelajaran diantaranya yaitu hasil penelitian Mustamilah (2015) yang berjudul "Peningkatan Keterampilan Proses dan Hasil Belajar menggunakan Model Problem Based 
Learning pada Sub Tema Merawat Tubuhku Peserta didik Kelas 1 SD Negeri 1 Gosono Wonosegoro" terlihat bahwa model PBL dapat : a) meningkatkan keterampilan Peserta didik dalam proses pemecahan masalah Tema 1 Sub Tema 3 tentang merawat tubuh Peserta didik kelas 1 SD NEGERI 1 GOSONO. Presentase kenaikan keterampilan pemecahan masalah sebesar $9,09 \%$ untuk siklus $1,11,36 \%$ untuk siklus 2, 13,63\% untuk siklus $3 . \quad$ b) meningkatkan presentase jumlah Peserta didik yang mencapai ketuntasan belajar minimal (KKM) pada Bahasa Indonesia sebagai berikut : pada kondisi awal presentase pencapaian KKM sebesar 22,7\% (5 Peserta didik), pada siklus 1 presentase meningkat menjadi 40,9\% (9 Peserta didik), pada siklus 2 presentase meningkat menjadi 59,09\%(13 Peserta didik), pada siklus 3 persentase meningkat menjadi $72,72 \%$ (16 Peserta didik).

\section{METODE PENELITIAN}

Jenis Penelitian yang digunakan adalah penelitian tindakan kelas. Penelitian tindakan kelas adalah suatu proses yang mengkaji masalah pembelajaran yang oleh peserta didik dan guru di dalam kelas melalui refleksi diri untuk memecahkan masalah secara sistematis, empiris, dan terkontrol (Sanjaya, 2016). Penelitian ini dilaksanakan di SDN 05 Padang Pasir Kota Padang. Subjek dalam penelitian ini adalah guru dan peserta didik kelas V SDN 05 Padang Pasir Kota padang. Peserta didik kelas V SD SDN 05 Padang Pasir Kota padang terdiri dari 25 peserta didik yaitu 15 laki-laki dan 10 perempuan. Penelitian ini melibatkan peneliti sebagai praktisi dan guru kelas $\mathrm{V}$ sebagai observer. Penelitian ini dilaksanakan dalam 2 siklus yatitu siklus 1 terdiri dari 1 pertemuan dan siklus 2 terdiri dari 1 pertemuan. Siklus 1 dilaksanakan pada hari Selasa, 16 Maret 2021 dan siklus 2 dilakasanakan pada hari Selasa, 23 Maret 2021.

Alur penelitian menggunakan model siklus.Peneliti merencanakan pelaksanaannya terdiri dari dua siklus. Apabila setelah diadakan siklus pertama, pencapaian masih jauh dari harapan, maka diadakan siklus kedua.
Penelitian tindakan kelas yang dilaksanakan menggunakan model siklus yang di kembangkan oleh Kemmis dan MC Taggart (dalam Arikunto, 2015) ada empat tahapan dalam siklus, yaitu perencanaan, pelaksanaan tindakan, pengamatan dan refleksi.

Peneliti merumuskan masalah yang akan diangkat sebagai masalah dalam penelitian, yaitu penggunaan model Problem Based Learning untuk meningkatkan hasil belajar peserta didik. Pada tahap proses penelitian ini terdiri dari perencanaan, pelaksanaan tindakan, pengamatan, dan refleksi. Tahap perencanaan dimulai dengan merumuskan rancangan pembelajaran berdasarkan model Problem Based Learning dengan kegiatan menetapkan jadwal selama penelitian, menganalisis Kurikulum 2013 kelas IV semester II, mengkaji buku guru dan buku peserta didik muatan pelajaran matematika pada materi pengolahan data, menyusun RPP sesuai dengan langkah-langkah model Problem Based Learning, menentukan materi pembelajaran, mempersiapkan media yang dibutuhkan dalam pelaksanaan pembelajaran, membuat Lembar Kerja Peserta Didik (LKPD), alat evaluasi untuk mengetahui pemahaman peserta didik terhadap materi yang telah dipelajari, dan menyusun instrumen penelitian (lembar observasi, lembar tes, kisi-kisi dan lembar penilaian).

Tahap pelaksanaan, guru melaksanakan pembelajaran dengan penerapan model pembelajaran sesuai dengan rancangan pembelajaran yang telah dibuat, observer melakukan pengamatan dengan menggunakan lembar observasi. Guru dan observer melakukan diskusi terhadap tindakan yang dilakukan, kemudian melakukan refleksi. Hasilnya dimanfaatkan untuk perbaikan atau penyempurnaan selanjutnya. Tahap pengamatan, guru dan observer mencatat semua indikator dari hasil pengamatan pembelajaran. Pengamatan dilakukan secara terus menerus dari siklus I, siklus ke II hingga hasil tampak mengalami peningkatan. Pengamatan yang dilakukan pada siklus I dapat mempengaruhi penyusunan tindakan pada siklus selanjutnya, begitupun dengan 


\section{PRIMARY: JURNAL PENDIDIKAN GURU SEKOLAH DASAR \\ VOLUME 10 NOMOR 4 AGUSTUS 2021 \\ ISSN : 2303-1514 | E-ISSN : 2598-5949 \\ DOI : http://dx.doi.org/10.33578/jpfkip.v10i4.8479 \\ https://primary.ejournal.unri.ac.id/index.php/JPFKIP}

siklus selanjutnya (siklus ke n). Hasil pengamatan ini kemudian didiskusikan dengan observer dan diadakan refleksi, untuk perencanaan siklus berikutnya.

Tahap refleksi, guru dan observer mengadakan diskusi terhadap tindakan yang dilakukan. Pertama, menganalisis tindakan yang dilakukan. Kedua, mengulas dan menjelaskan perbedaan rencana dan pelaksanaan tindakan yang telah dilakukan. Ketiga, perkembangan belajar yang dicapai peserta didik. Keempat, melakukan tindakan, dan penyimpulan data yang diperoleh.

Data-data dari penelitian yang akan peneliti lakukan berupa hasil pengamatan terhadap pelaksanaan pembelajaran dalam muatan pelajaran matematika materi pengolahan data dengan menggunakan model Problem Based Learning di kelas V SDN 05 Padang Pasir Kota Padang berkaitan perencanaan dan pelaksanaan dengan penjelasan sebagai berikut: a) RPP menggunakan model Problem Based Learning meliputi lembar observasi, LKPD, dan lembar penilaian, b) Pelaksanaan pembelajaran yang berhubungan dengan aspek guru dan aspek peserta didik dalam pembelajaran dengan menggunakan model Problem Based Learning, c) Peningkatan hasil belajar peserta didik pada pembelajaran tematik terpadu setelah diterapkan model Problem Based Learning.

Sumber data dalam penelitian ini adalah pelaksanaan pembelajaran tematik terpadu menggunakan model Problem Based Learning. Data diperoleh dari subjek yang akan diteliti, yakni guru dan peserta didik kelas V SDN 05 Padang Pasir Kota Padang. Data dalam penelitian ini dikumpulkan dengan menggunakan teknik observasi dan tes. Penelitian ini menggunakan beberapa instrument untuk mengumpulkan data, yaitu lembar observasi, lembar soal, jurnal sikap, dan rubrik penilaian keterampilan.

Data yang diperoleh dari penelitian ini dianalisis dengan menggunakan analisis data kualitatif dan kuantitatif. Data kualitatif adalah data yang disajikan dalam bentuk kata-kata yang mengandung makna. Menurut Miles dan Huberman (dalam Sugiyono, 2016: 337) analisis data kualitatif mencakup tiga kegiatan yang bersamaan, yaitu a) reduksi data, b) penyajian data, c) penarikan kesimpulan. Data kuantitatif data yang disajikan dalam bentuk angka. Teknik analisis data kuantitatif dilakukan terhadap hasil belajar Peserta didik yaitu aspek pengetahuan dan keterampilan dengan menggunakan indeks Nilai Kuantitatif dengan skala 0-100 dengan KKM 75 (B) yang dikemukan oleh Kemendikbud (2014) sebagai berikut:

$$
\text { Nilai }=\frac{\text { Skor yang diperoleh }}{\text { Skor maksimal }} \times 100
$$

\section{HASIL DAN PEMBAHASAN}

\section{Hasil Penelitian}

\section{Hasil Siklus I}

Hasil penelitian pada siklus I terdiri dari rencana pelaksanaan pembelajaran dan proses pelaksanaan model pembelajaran problem based learning.

Tahap Perencanaan

Penyusunan perencanaan tindakan pembelajaran Matematika dengan menggunakan model PBL dilakukan berdasarkan Kurikulum 2013 matematika kelas V semester II dan dituangkan dalam bentuk RPP. Perencanaan disusun untuk satu kali pertemuan yaitu 3 jam pelajaran 3 x 35 menit. Kompetensi Dasar yang dilaksanakan pada siklus I adalah Kompetensi Dasar 3.7 menjelaskan data yang berkaitan dengan diri Peserta didik atau lingkungan sekitar serta cara pengumpulannya, dan 4.7 mengidentifikasi data yang berkaitan dengan diri Peserta didik atau lingkungan sekitar serta cara pengumpulannya.

Sebelum pelaksanaan pembelajaran berlangsung, terlebih dahulu peneliti mempersiapkan rencana pelaksanaan pembelajaran (RPP), Lembar Kerja Peserta didik (LKPD), dan lembar evaluasi yang terdiri dari 5 soal essay serta kunci jawaban evaluasi yang akan digunakan dalam pembelajaran. Di samping itu peneliti juga menyiapkan lembar pengamatan yang akan diberikan pada observer yang digunakan untuk proses pembelajaran baik aspek guru maupun aspek Peserta didik dalam pembelajaran matematika dengan menggunakan model PBL. 
Selain itu peneliti juga mempersiapkan media pembelajaran yakni power point yang berisikan penjelasan materi cara pengumpulan data dan penetapan masalah.

\section{Tahap Pelaksanaan}

Pelaksanaan pembelajaran didasari oleh penerapan langkah model pembelajaran PBL. Peserta didik dibimbing guru menetapkan permasalahan yang mana permasalahannya berkaitan dengan kehidupan sehari-hari peserta didik. Guru mengorganisasikan peserta didik untuk belajar dengan cara guru membagikan peserta didik kedalam beberapa kelompok. Peserta didik dibimbing oleh guru melakukan penyelidikan dengan kelompok masing-masing. Peserta didik mengembangkan dan mempersiapkan laporan penyajian dari solusi yang dilakukan. Peserta didik setelah melakukan pengumpulan data solusi dari permasalahan yang ditetapkan, Peserta didik akan mengurutkan data terlebih dahulu dari terendah ke tertinggi. Guru menjelaskan penggunaan Ms. Excel. Peserta didik dibimbing guru untuk mengurutkan data di Ms. Excel. Peserta didik menganalisi nilai tertinggi dan nilai terendah. Selanjutnya Peserta didik melakukan persentasi pemecahan masalah yang kelompok lakukan. Peserta didik dan guru melakukan analisis dan evaluasi terhadap kelompok yang mempersentasikan hasil pemecahan masalah. Peserta didik menganalisis setiap pemecahan masalah kelompok yang tampil. Terakhir Peserta didik melakukan penyamaan persepsi. Kelompok Peserta didik yang berhasil melakukan pemecahan masalah diberikan penghargaan.

\section{Tahap Pengamatan}

Pengamatan terhadap perencanaan pembelajaran (RPP) dilaksanakan melalui lembar pengamatan RPP dengan aspek penilaian. Ada 9 Karakteristik dari rpp yang di nilai. Berdasarkan hasil pengamatan yang dilakukan oleh pengamat terhadap aktivitas peneliti pada pembelajaran siklus I jumlah skor yang diperoleh 32 dari skor maksimal 36. Dengan demikian, persentase nilai pada aktivitas guru ini adalah $88,8 \%$. Hal ini menunjukkan bahwa kategori keberhasilan terhadap pengamatan dalam perancangan RPP sudah termasuk dalam kategori sangat baik (SB).

Pengamatan Pelaksanaan

Pembelajaran (Guru dan Peserta Didik). Berdasarkan hasil pengamatan yang dilakukan oleh pengamat terhadap aktivitas guru dan peserta didik dalam kegiatan pembelajaran siklus I, jumlah skor yang diperoleh 21 dari skor maksimal 28. Dengan demikian, persentase nilai pada aktivitas peserta didik ini adalah $75 \%$. Hal ini menunjukkan bahwa kategori keberhasilan aktivitas guru dan peserta didik termasuk dalam kategori baik.

\section{Tahap Refleksi}

Pada tahapan ini pengamatan yang peneliti peroleh dibahas bersama dengan observer. Refleksi tindakan siklus I ini meliputi refleksi rencana pembelajaran, refleksi pelaksanaan pembelajaran dan refleksi hasil belajar. Refleksi Rencana Pembelajaran ditemukan ada beberapa aspek pada RPP yang mesti harus diperbaiki untuk pertemuan selanjutnya, diantaranya: (1) Pada aspek materi pembelajaran, sumber belajar dan media pembelajaran.

Refleksi pelaksanaan pembelajaran berkaitan langsung dengan rencana pelaksanaan pembelajaran (RPP) yang telah dibuat. Berdasarkan hasil pengamatan dan diskusi yang dilakukan dengan observer pada siklus I diketahui bahwa pelaksanaan perencanaan pembelajaran matematika dengan menggunakan model problem based learning belum terlaksana dengan baik.

Refleksi Hasil Belajar dilihat dari akumulasi dari keseluruhan hasil belajar peserta didik dalam pembelajaran matematika materi pengolahan data dengan menggunakan model pembelajaran problem based learning pada siklus I ini menunjukkan hasil yang belum maksimal yakni memperoleh nilai ratarata 66,4. Dengan demikian, penggunaan model problem based learning dalam pembelajaran matematika materi pengolahan data dengan tujuan meningkatkan hasil belajar peserta didik masih perlu ditingkatkan lagi pada siklus II dengan mempertimbangkan masalah-masalah yang muncul selama siklus I.

\section{Hasil Siklus II}




\section{Tahap Perencanaan}

Tahapan perencanaan tindakan pembelajaran matematika menggunakan model problem based learning dilakukan berdasarkan Kurikulum 2013 dan dituangkan dalam bentuk RPP matematika kelas V semester II. RPP siklus II merupakan perbaikan dari refleksi terhadap RPP siklus I.

\section{Tahap Pelaksanaan}

Pelaksanaan pembelajaran siklus II didasari oleh penerapan langkah model pembelajaran PBL sebagaimana dilaksanakan pada siklus I.

\section{Tahap Pengamatan}

Secara keseluruhan hasil pengamatan pada siklus II. Pada pengamatan terhadap 9 komponen besar yang diamati oleh observer dalam RPP menggunakan model problem based learning, pengamatan yang dilakukan oleh pengamat terhadap aktivitas peneliti pada pembelajaran siklus II jumlah skor yang diperoleh 35 dari skor maksimal 36. Dengan demikian, persentase nilai pada aktivitas guru ini adalah 97,2\%. Hal ini menunjukkan bahwa kategori keberhasilan terhadap pengamatan dalam perancangan RPP sudah termasuk dalam kategori sangat baik (SB).

Pengamatan terhadap aktivitas guru dan peserta didik dalam kegiatan pembelajaran sudah terlihat perubahan ke arah yang lebih baik, dimana dalam pelaksanaanya sudah mulai terlaksana dengan maksimal sesuai dengan rencana yang telah disusun. Berikut data yang diperoleh dari pembelajaran menggunakan model problem based learning. Berdasarkan hasil pengamatan yang dilakukan oleh pengamat terhadap aktivitas guru dan peserta didik dalam kegiatan pembelajaran siklus II jumlah skor yang diperoleh 20 dari skor maksimal 20. Dengan demikian, persentase nilai pada aktivitas guru ini adalah $100 \%$. Hal ini menunjukkan bahwa kategori keberhasilan aktivitas guru termasuk dalam kategori sangat baik (SB).

\section{Tahap Refleksi}

Refleksi tindakan siklus II ini mencakup refleksi rencana pembelajaran, proses pembelajaran dan refleksi hasil belajar peserta didik. Refleksi dalam perencanaan pembelajaran pada siklus II sudah lebih baik dari siklus I, hal ini dikarenakan hampir setiap langkah pada RPP semuanya sudah terlihat dengan baik dan rencana sudah terlaksana seperti yang seharusnya pada proses pembelajaran. Refleksi Pelaksanaan Pembelajaran merupakan diskusi peneliti dan observer didapatkan kesimpulan bahwa pelaksanaan model problem based learning pada proses pembelajaran matematika siklus II sudah berhasil, hal ini dikarenakan oleh semua langkah pembelajaran sudah sesuai pencapaian berdasarkan hasil pengamatan telah mencapai kualifikasi Sangat Baik, dengan alokasi waktu yang sudah ditentukan pada RPP. Diantaranya adalah : pada semua langkah model problem based learning, orientasi peserta didik pada masalah, mengorganisasi peserta didik untuk belajar, membimbing penyelidikan individual maupun kelompok, mengembangkan dan menyajikan hasil karya serta menganalisis dan mengevaluasi proses pemecahan masalah, semua memperoleh skor 4 dengan prediket sangat baik.

Refleksi Hasil Belajar didapati hasil pengamatan observer, aktivitas dari aktivitas peserta didik telah mencapai kualifikasi sangat baik (SB). Hasil penilaian pembelajaran peserta didik dalam proses pembelajaran matematika dengan menggunakan model problem based learning pada siklus II memperoleh nilai rata-rata dengan predikat $\mathrm{A}$ dan persentase ketuntuntasan $100 \%$ dengan kategori sangat baik (SB). Jumlah peserta didik yang tuntas yaitu 25 orang peserta didik.

\section{PEMBAHASAN}

Pada pembahasan akan dibahas mengenai hasil penelitian yang telah di jelaskan di atas. Pembahasan hasil penelitian meliputi proses pembelajaran dan hasil belajar. Pembahasan didasarkan pada teori yang berkaitan dengan peningkatan proses pembelajaran matematika dengan menggunakan model problem based learning pada peserta didik kelas V SDN 05 Padang Pasir Kota Padang. Dari hasil penelitian pelaksanaan pembelajaran model problem based learning pada pembelajaran matematika 
materi pengolahan data di kelas V SDN 05 Padang Pasir Kota Padang terungkap bahwa guru membuat perencanaan pembelajaran dalam bentuk Rencana Pelaksanaan Pembelajaran (RPP).

\section{RPP Matematika Materi Pengolahan Data Menggunakan Model Problem Based Learning}

Rencana pembelajaran pada siklus 1 ini baru memperoleh 32 dari skor maksimal 36 dengan persentase $88,8 \%$, sedangkan rencana pembelajaran pada siklus II pembelajaran matematika menggunakan model problem based learning sudah terlaksana dengan baik karena RPP sudah memenuhi semua komponen dan setiap langkah yang ada pada RPP semuanya sudah terlaksana dengan baik pada saat pelaksanaan pembelajaran siklus II dan memperoleh skor maksimal yaitu 36 dari skor maksimal 36 dengan presentase $100 \%$. Peningkatan pada Rencana Pembelajaran matematika materi pengolahan data.

\section{Pembelajaran Matematika dengan Materi Pengolahan Data Menggunakan Model Problem Based Learning}

Berdasarkan perencanaan yang disusun, pelaksanaan proses pembelajaran disajikan dalam dua kali pertemuan. Siklus I dua kali pertemuan dan siklus II dua kali pertemuan, setiap pertemuan dilaksanakan selama 3x35 menit. Dari hasil penelitian pelaksanaan proses pembelajaran dengan model problem based Learning materi pengolahan data di kelas V SDN 05 Padang Pasir. Diperolah data hasil pelaksanaan proses pembelajaran, maka hasil pengamatan aspek aktivitas guru pada siklus I adalah $75 \%$ dengan kriteria baik meningkat pada siklus II meningkat menjadi 100\% dengan kategori sangat baik. Sedangkan pengamatan aspek peserta didik siklus I adalah $75 \%$ dengan kriteria baik meningkat pada siklus II menjadi $100 \%$ kriteria sangat baik. Proses pembelajaran pada matematika dalam materi pengolahan data dengan menggunakan model problem based learning di kelas V SD meningkat dari aspek peserta didik maupun aspek guru.

\section{Hasil Belajar Matematika Materi Pengolahan Data dengan Menggunakan Model Problem Based Learning}

Pelaksanaan proses pembelajaran yang sudah berjalan cukup baik juga berpengaruh pada penilaian hasil belajar peserta didik. Penilaian hasil belajar dilakukan dengan penilaian autentik. Hargreaves dkk dalam Majid (2014) mengemukakan "Penilaian autentik adalah sebuah bentuk penilaian yang mencerminkan hasil belajar yang sesungguhnya, dapat menggunakan berbagai cara atau bentuk, antara lain melalui penilaian proyek, portofolio, jurnal, demonstrasi, laporan tertulis, ceklis, dan petunjuk obsevasi". Penilaian autentik dalam proses pembelajaran dilihat dari aspek sikap, pengetahuan, dan keterampilan.

Pada siklus I, aspek sikap pada siklus I terdapat 5 orang peserta didik yang menonjolkan sikap negatif dan 3 orang peserta didik menonjolkan sikap positif, aspek pengetahuan memperoleh presetanse ketuntasan $40 \%$ dengan predikat Kurang (K) pada siklus I meningkat pada siklus II menjadi 100\% kategori sangat baik (SB). Aspek keterampilan pada siklus I memperoleh presetanse ketuntasan $40 \%$ dengan prediket kurang (K) meningkat pada siklus II menjadi $100 \%$ kategori sangat baik (SB). Hasil belajar matematika materi pengolahan data dengan menggunakan model problem based learning meningkat.

\section{SIMPULAN DAN REKOMENDASI}

Dari uraian data, hasil penelitian, dan pembahasan dalam BAB IV simpulan yang dapat diambil dari penelitian ini adalah sebagai berikut:

Rencana Pelaksanaan Pembelajaran menggunakan model problem based learning dalam pembelajaran tematik terpadu di kelas V SDN 05 Padang Pasir dituangkan pada RPP yang langkah-langkah penyusunannya terdiri dari (1) identitas RPP, (2) KI, (3) Kompetensi Dasar dan indikator,(4) tujuan pembelajaran, (5) materi pembelajaran, (6) metode, model 
dan pendekatan pembelajaran,(7) media, alat dan sumber belajar , (8) Langkah pembelajaran, serta (9)penilaian.

1. Pelaksanaan Pembelajaran pada pembelajaran tematik terpadu kelas V SDN 05 Padang Pasir menggunakan model problem based learning terdiri dari kegiatan pendahuluan, inti dan penutup. Pada proses pembelajaran menggunakan model problem based learning telah berhasil meningkatkan keaktifan siswa.

2. Hasil belajar siswa dalam pembelajaran tematik terpadu menggunakan model problem based learning kelas V SDN 05 Padang Pasir mengalami peningkatan yang signifikan. Terlihat dari hasil siklus I memperoleh nilai rata-ratanya 68,95 kategori baik (dengan persentase ketuntasan $40 \%$ dengan kategori kurang) meningkat menjadi rata-rata 87,8 kategori sangat baik (dengan persetase ketuntasan $100 \%$ kategori sangat baik) pada siklus II

Dari hasil simpulan, peneliti memberikan beberapa rekomendasi sebagai berikut:

1. Untuk sekolah, yaitu menjadikan model problem based learning sebagai inovasi dalam proses pembelajaran yang dapat diterapkan oleh guru.

2. Untuk peneliti lain, yaitu dapat dijadikan acuan dalam penelitian selanjutnya dan dapat menggunakan model problem based learning sebagai model yang tepat untuk meingkatkan hasil belajar siswa.

\section{DAFTAR PUSTAKA}

Arikunto, S., Suhardjono dan Supardi. (2015). Penelitian Tindakan Kelas. Jakarta: Bumi Aksara

Mustamilah. (2015). Peningkatan Keterampilan Proses Dan Hasil Belajar Menggunakan Model Problem Based Learning Pada Sub Tema Merawat Tubuhku Siswa Kelas 1 Sd Negeri 1 Gosono - Wonosegoro. Scholaria, 5, 92-102.

Ngalimun. (2017). Strategi Pembelajaran. Yogyakarta: Parama Ilmu.

Purnamasari, Y., dan Desyandri. (2018). Peningkatan Pembelajaran Tematik dengan Pendekatan Scientific di Kelas I SDN 15 Ulu Gadut Kota Padang. Jurnal Inovasi Pembelajaran SD, 6, $11-24$.

Sanjaya, W. (2016). Strategi Pembelajaran Berorientasi Standar Proses pendidikan. Jakarta: Kencana Prenada Media.

Sugiyono. (2016). Metode Penelitian. Bandung : Alfabeta

Sudjana, N., \& Ibrahim. (2007). Penelitian dan Penilaian dalam Pendidikan. Bandung: C.V Sinar Baru.

Tarigan, D. (2006). Pembelajaran Matematika Realistik. Jakarta: Depdiknas.

Trianto. (2014). Mendesain Model Pembelajaran Inovatif Progesif. Cetakan ke- 4. Surabaya: Kencana

Widiasworo, E. (2017). Strategi dan Metode Mengajar di Luar Kelas. Yogyakarta: Ar-Ruzz Media. 